\title{
Średniowieczne malarstwo ścienne w kamienicach mieszczańskich Torunia Najnowsze odkrycia
}

\author{
Monika Jakubek-Raczkowska \\ Juliusz Raczkowski \\ Wydziat Sztuk Pięknych \\ UMK Toruń
}

Zasób pozostałości średniowiecznych wystrojów malarskich kamienic mieszczańskich, jaki przetrwał w obrębie toruńskiej Starówki i był stopniowo odsłaniany począwszy od lat pięćdziesiątych XX w. ${ }^{1}$, należy do najbogatszych w tej części Europy. Nie licząc malowideł, które z różnych przyczyn po odkryciu zostały wtórnie zatynkowane i nie są dziś eksponowane ${ }^{2}$, katalog toruńskich polichromii mieszczańskich o czytelnej formie figuralnej lub ornamentalnej ${ }^{3}$ liczy 31 przykładów

\footnotetext{
${ }^{1}$ Pomijając przypadkowe odkrycie malowideł w wyburzanym w 1906 r. domu przy Rynku Staromiejskim 36 (zostały one udokumentowane na dwóch fotografiach), pierwszym toruńskim zabytkiem tego typu, odsłoniętym i poddanym pracom zabezpieczającym, były polichromie w kamienicy przy ul. Szczytnej 15, odkryte w 1952 r. Zob. J. Frycz, Nowoodkryte dekoracje malarskie $w$ spichrzu przy ul. Szczytnej $w$ Toruniu, Biuletyn Historii Sztuki 17 (1955), z. 2, s. 275-276.

${ }^{2}$ Do wtórnego wysłonięcia odkrytych malowideł doszło w kilku przypadkach - przy ulicach Łaziennej 4, Szczytnej 2/4, Szerokiej 15 oraz Żeglarskiej 17/19.

${ }^{3}$ Katalog taki został opracowany przez autorów, przy współpracy T. Kowalskiego, w ramach projektu pt. „Katalog polichromii ściennych we wnętrzach świeckich na terenie Starego i Nowego Miasta Torunia (od końca XIII do pocz. XVI w.)", realizowanego pod auspicjami Towarzystwa Naukowego w Toruniu przy finansowym wsparciu Urzędu Miasta Torunia: http://tnt. torun. pl/pl/projekty/dzieje-i-kultura-torunia-i-regionu/katalogpolichromii-sciennych (dostęp na dzień 5 XI 2017). Jego efektem jest monograficzna publikacja: M. Jakubek-Raczkowska, J. Raczkowski, T. Kowalski (współpr.), Średniowieczne malowidła ścienne w kamienicach mieszczańskich Starego i Nowego Miasta Torunia / The Medieval Wall Paintings in The Burgher Houses of the Old and New Town
} 
pochodzących spod 28 adresów ${ }^{4}$. Zespół ten dopełniają pozostałości skromniejszych barwnych wykończeń, takich jak malowane bezpośrednio na cegle szare pasy czy dwubarwne dekoracje obramień blend i wnęk ściennych (il. 1). Odkrycia ostatniej dekady - znacząco uzupełniające stan dotychczasowej wiedzy o warsztacie, treściach i formach tego malarstwa ${ }^{5}$ - wskazują, że zasób ten wciąż jeszcze może się powiększyć o nowe, nieznane dotąd zabytki.

of Toruń, Toruń 2017 (w druku). Zob. także artykuł J. Raczkowskiego, Najnowsze badania nad malarstwem ściennym w mieszczańskich przestrzeniach świeckich średniowiecznego Torunia, [w:] Claritas et consonantia. Funkcje, formy i znaczenia w sztuce średniowiecza. Księga poświęcona pamięci Kingi Szczepkowskiej-Naliwajek w dziesiata rocznicę śmierci, red. M. Jakubek-Raczkowska, J. Raczkowski, Toruń-Warszawa 2017 , s. $513-529$.

${ }^{4} \mathrm{~W}$ tym, jak dotąd, tylko dwa przykłady odkryto w kamienicach zlokalizowanych w obrębie dawnego Nowego Miasta Torunia (ul. Królowej Jadwigi 9 oraz Wielkie Garbary 7).

${ }^{5} \mathrm{~W}$ dotychczasowym, stosunkowo skromnym stanie badań nad średniowiecznym malarstwem ściennym w kamienicach Torunia na plan pierwszy wysuwają się opracowania Jerzego Domasłowskiego: Uwagi o programach ideowych i systemach dekoracyjnych gotyckich malowidet ściennych w budowlach świeckich na terenie Prus Krzyżackich i Królewskich, [w:] Sztuka Pobrzeża Bałtyku. Materiaty sesji SHS Gdańsk, listopad 1976, red. H. Fruba, Warszawa 1978, s. 143-165; Malowidła ścienne w toruńskich średniowiecznych wnętrzach mieszczańskich, Rocznik Muzeum w Toruniu 8 (1982), s. 28-43; Weltliche Wandmalereien in weltlichen Bauten zu Thorn, Zeitschrift für Kunstgeschichte 53 (1990), H. 2, s. 150-159. Uwagi na temat dzieł zachowanych w kamienicach były też włączane przez tego badacza do przekrojowych studiów, por. m.in. Polska pótnocno-wschodnia (Pomorze Wschodnie), [w:] A. Karłowska-Kamzowa, J. Domasłowski, M. Kornecki, H. Małkiewiczówna, Gotyckie malowidła ścienne w Polsce. Wyniki badań przeprowadzonych w latach 1974-1979, Ochrona Zabytków 33/2 (1980), s. 132-140; Tom III. Polska pótnocno-wschodnia, [w:] Materiały do katalogu gotyckich malowidel ściennych w Polsce, red. A. Karłowska-Kamzowa, Poznań 1981, s. 41-61; Pomorze Wschodnie, [w:] Gotyckie malarstwo ścienne w Polsce, red. A. Karłowska-Kamzowa (Uniwersytet im. Adama Mickiewicza w Poznaniu, seria „Historia sztuki” 17), Poznań 1984, s. 121-162; Malarstwo ścienne, [w:] J. Domasłowski, A. Karłowska-Kamzowa, A. Labuda, Malarstwo gotyckie na Pomorzu Wschodnim, („Prace Komisji Historii Sztuki” 17), Warszawa-Poznań 1990, s. 10-64; Krzyżacy, biskupi, mieszczanie... Malowidła ścienne w państwie zakonnym i krag fundatorów do połowy XV wieku, [w:] Fundacje artystyczne na terenie państwa krzyżackiego w Prusach. Katalog wystawy w Muzeum Zamkowym w Malborku, red. B. Pospieszna, t. 2: Eseje, Malbork 2010, s. 106-141. 
Stan zachowania toruńskiego zespołu polichromii nie jest zbyt dobry. Większość pozostałości to jedynie relikty (niekiedy bardzo niewielkie) dużych kompozycji o nieznanym dziś zasięgu i treściach (il. 2). Warstwy malarskie, poddawane różnym zabiegom konserwatorskim i restauratorskim, zachowane są na ogół dość słabo. Mimo to cały ten zespół ma bardzo duży potencjał badawczy z punktu widzenia studiów nad mieszczańską kulturą materialną, a także - nad mentalnością miejskich elit. Celem niniejszego artykułu jest charakterystyka kilku odkrytych w ciągu ostatniej dekady i wciąż jeszcze mało znanych przykładów polichromii toruńskich wnętrz świeckich oraz zaakcentowanie ich naukowej i historycznej wartości. Są to cztery zabytki: odkryte i odrestaurowane w 2007 r. malowidło z prorokiem w kamienicy przy ul. Różanej 16; odkryte w $2007^{7}$ i poddane konserwacji w 2011 r. ${ }^{8}$ malowidło z Pokłonem Trzech Króli i Walka św. Jerzego ze smokiem w kamienicy przy Rynku Staromiejskim 109; odkryte w 2015 i konserwowane w 2016 r. pozo-

\footnotetext{
${ }^{6}$ Malowidło to było, jak dotąd, przywoływane w kilku opracowaniach, por.: A. Błażejewska, E. Pilecka, Sztuka średniowieczna, [w:] A. Błażejewska, K. Kluczwajd, B. Mansfeld, E. Pilecka, J. Tylicki, Dzieje sztuki Torunia, Toruń 2009, s. 99, 135, il. 121; J. Domasłowski, Krzyżacy, biskupi, mieszczanie, s. 140; J. Raczkowski, Najnowsze odkrycia w zakresie gotyckiego malarstwa ściennego w Prusach i ich znaczenie dla badań nad sztuka regionu, [w:] Homo Creator et Receptor Artium. Księga pamiątkowa Księdzu Profesorowi Stanisławowi Kobielusowi ofiarowana, red. M. Wrześniak, Warszawa 2010, s. 89-104, zwł. s. 92, 93; E. Pilecka, Typowe czy wyjątkowe? Odkrywane elementy wystroju średniowiecznej architektury Torunia, Acta Universitatis Nicolai Copernici, Zabytkoznawstwo i Konserwatorstwo 46 (2015), s. 13-43, zwł. s. 22, 24.

${ }^{7}$ Obecność polichromii stwierdzono we wtórnie zamurowanej wnęce wielkiej sieni podczas badań architektonicznych prowadzonych w kamienicy w 2006 r., zob. J. Kucharzewska, P. Dąbrowski, Dokumentacja konserwatorska. Rozwarstwienia chronologiczne. Ul. Rynek Staromiejski 10, Toruń 2006, s. 22 (dostęp: Archiwum Biura Miejskiego Konserwatora Zabytków w Toruniu). Pozostałości kompozycji malarskiej zostały odsłonięte w 2007 r. i poddane zachowawczej konserwacji w latach 2007-2009, zob.: J. Kucharzewska, Dokumentacja powykonawcza prac budowlano-konserwatorskich w budynku przy Rynku Staromiejskim 10 w Toruniu. Cz. I: parter, I piętro, II piętro i poddasze, Toruń 2009, s. 25, 27, il. 31, 32 (dostęp: archiwum własne autorki dokumentacji).

${ }^{8}$ Pełna konserwacja została przeprowadzona w 2011 r. przez mgr Elżbietę Rogozińską, zob.: E. Rogozińska, Malowidło ścienne w kamienicy przy Rynku Staromiejskim 10 w Toruniu. Dokumentacja prac konserwatorskich, Torun 2011 (dostęp: Archiwum Biura Miejskiego Konserwatora Zabytków w Toruniu).

${ }^{9}$ Niepublikowane.
} 


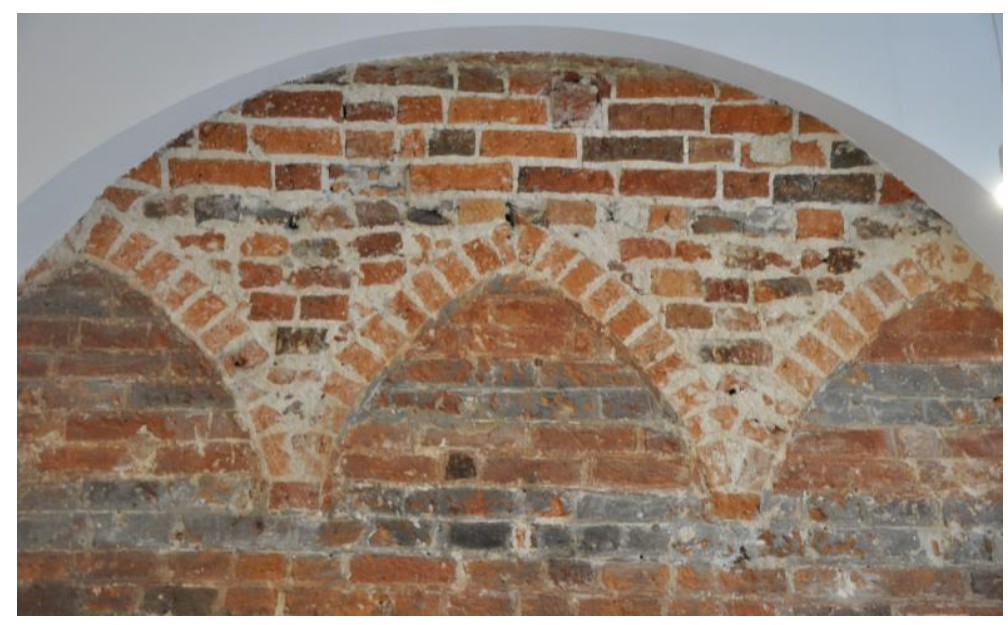

Il. 1. Toruń, kamienica przy Rynku Staromiejskim 25. Średniowieczna dekoracja lica muru w obrębie dawnej sieni, fot. J. Raczkowski

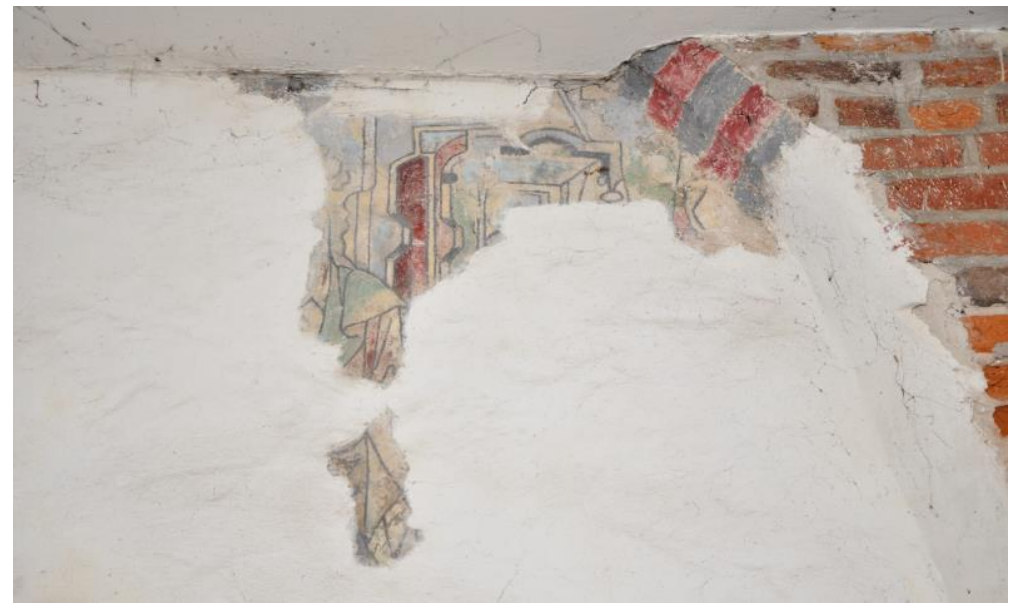

Il. 2. Toruń, kamienica przy ul. Łaziennej 8. Nierozpoznane malowidło ścienne (fragment postaci świętej w obramieniu architektonicznym) w niszy ściennej przelotu bramnego (dawna wielka sień), 3. ćw. XIV w., fot. J. Raczkowski 
stałości malowidła z trzema świętymi w domu przy ul. Kopernika $6^{10}$, wreszcie - odsłonięte w końcu 2016 r. i poddawane pracom konserwatorskim do połowy roku $2017^{11}$ - relikty wystroju pomieszczenia w kamienicy przy ul. Żeglarskiej $16^{12}$ (Modlitwa w Ogrójcu oraz fragment cyklu Dziewięciu Bohaterów). Wszystkie cztery dzieła wzbogacają znacząco zasób mieszczańskich dekoracji figuralnych znanych z XIV w. Dwa $\mathrm{z}$ nich przetrwały $\mathrm{w}$ dawnych sieniach, dwa - we wnętrzach dawnych świetlic na drugiej kondygnacji. Pod względem lokalizacji w dawnej przestrzeni domu nie należą one zatem do wyjątków: zasadnicza większość rozpoznanego dotąd zasobu mieszczańskich malowideł toruńskich to dekoracje reprezentacyjnych pomieszczeń, zachowane w kamienicach będących niegdyś w rękach prominentnych właścicieli i położonych w historycznym centrum dawnego Starego Miasta.

Malowidła z domów przy Rynku Staromiejskim 10 i przy ul. Kopernika 6 należą do ośmiu znanych w Toruniu przykładów wystroju tzw. wielkich sieni - najważniejszych pomieszczeń w kamienicach w typie kupieckiego ,domu-składu” (zwanego także „,sieniowym” - niem. Die-

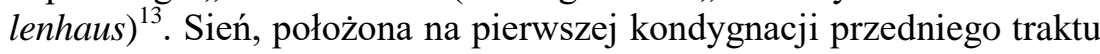
kamienicy, nieco wyniesiona ponad poziom ulicy dzięki wysokiemu pod-

\footnotetext{
${ }^{10}$ Niepublikowane.

${ }^{11}$ Konserwację i restaurację przeprowadził zespół pod kierunkiem Hanny Belczyk, której składamy w tym miejscu podziękowania za umożliwienie nam dostępu do malowideł podczas trwających prac.

${ }^{12}$ Niepublikowane.

${ }^{13}$ Dom szczytowy z tzw. wielką / wysoką sienią (średnio 4-5,5 m wys., w Toruniu nawet do $6 \mathrm{~m}$ ) w pierwszej kondygnacji (niem. Dielenhaus) uformował się w 2. poł XIII w. w wyniku ewolucji miejskiego budownictwa murowanego na terenach dolnoniemieckich. Szczególną rolę w wykształceniu tego typu odegrała Lubeka. Zob. m.in. W. Erdmann, Entwicklungstendenzen des Lübecker Hausbaus 1100 - bis um 1340. Eine Ideenskizze, Lübecker Schriften zur Archäologie und Kulturgeschichte 7 (1983), s. 19-38, zwł. s. 24-25; tenże, Das mittelalterliche Stadthaus. Bemerkungen zu Form und Funktion anhand Lübecker Beispiele, [w:] Mensch und Umwelt im Mittelalter, Hg. B. Herrmann, Stuttgart 1987, s. 170-179, zwł. s. 174-177; G. Ditmar-Trauth, Die Entstehung des deutschen Bürgerhauses im Mittelalter. Eine Bestandsaufnahme bisheriger Erkenntnisse auf der Basis archäologischer und bauhistorischer Befunde, WaldMichelbach 2002, s. 37-40; o toruńskich kamienicach: E. Gąsiorowski, Toruńska kamienica mieszczańska, Zeszyty Naukowe UMK, Nauki Humanistyczno-Społeczne, z. 16, Zabytkoznawstwo i Konserwatorstwo 1 (1966), s. 69-110; Z. Nawrocki, Pięć kamienic mieszczańskich na ulicy Kopernika w Toruniu, Kwartalnik Architektury i Urbanistyki
} 
piwniczeniu, stanowiła centralne, najwyższe pomieszczenie domów tego typu. W kamienicach toruńskich jej ściany członowane były za pomocą naprzeciwległych, szerokich, płytkich nisz ściennych ${ }^{14}$, zamkniętych łukiem pełnym (jak w domu przy ul. Kopernika 15 lub Szerokiej 16) albo ostrołukiem (np. w kamienicach przy ul. Łaziennej 8 lub Żeglarskiej 10), sięgających od posadzki niemal po strop pomieszczenia i ujętych $w$ profilowane lub fazowane obramienia. Funkcjonalnie wielka sień była podzielona na dwie części. Część przednia, dość dobrze doświetlona oknami fasady ${ }^{15}$, powiązana była $\mathrm{z}$ życiem zawodowym, a w domach kupieckich elit pełniła także funkcje reprezentacyjne. Część tylna, „domowa”, mieszcząca tzw. kąt kuchenny, odgrywała z kolei zasadniczą rolę $\mathrm{w}$ życiu codziennym ${ }^{16}$ i skomunikowana była $\mathrm{z}$ tzw. izbą tylną. Funkcjonalny podział wnętrza na dwie części warunkował, jak się wydaje, lokalizację malowideł. Wszystkie znane z Torunia dekoracje malarskie sieni znajdują się na ścianach bocznych przedniej części pomieszczenia i wykorzystują nisze ścienne flankujące wejście ${ }^{17} . \mathrm{Z}$ racji ich wyeksponowania tuż przy wejściu dzieła te można traktować jako ostentacyjny symbol statusu właścicieli domu.

30/2 (1985), s. 197-225, zwł. s. 204-212; ostatnio syntetycznie: tenże, Historyczne kamienice w Toruniu. Gotyk, Torun 2016, s. 13-15.

${ }^{14} \mathrm{~W}$ niektórych domach zachowała się tylko para w części przedniej; w nielicznych przypadkach na każdej ścianie znajdowały się po dwie nisze - np. Rynek 35, Żeglarska 10.

${ }^{15}$ Pozostała część pomieszczenia musiała być doświetlana sztucznie, na co zwrócił uwagę Z. Nawrocki, Historyczne kamienice, s. 147.

${ }_{16}$ Było to miejsce przygotowywania i spożywania posiłku, robót domowych, a czasem nawet snu, zob. F. Kaspar, Das mittelalterliche Haus als öffentlicher und privater Raum, [w:] Die Vielfalt der Dinge. Neue Wege zur Analyse mittelalterlicher Sachkultur. Internationaler Kongress Krems an der Donau 4 bis 7 Oktober 1994. Gedenkschrift in memoriam Harry Kühnel, Hg. H. Hundsbichler, G. Jaritz, T. Kühtreiber, Wien 1998, s. 207-235, zwł. s. 215; C. Meckseper, Wandmalerei im funktionalen Zusammenhang ihres architektonisch-räumlichen Orts, [w:] Literatur und Wandmalerei I. Erscheinungsformen höfischen Kultur und ihre Träger im Mittelalter. Freiburger Colloquium 1998, Hg. E. C. Lutz, J. Thali, R. Wetzel, Tübingen 2002, s. 255-281, zwł s. 273 ; por. też obrazowy opis konsekwencji skumulowania wszystkich czynności w jednym miejscu: Z. Nawrocki, Historyczne kamienice, s. 146-147.

${ }^{17} \mathrm{~W}$ żadnej toruńskiej kamienicy nie przetrwały też relikty polichromii, które pozwoliłyby stwierdzić z całą pewnością, czy dekorowano obie nisze przedniej części sieni ani czy dekoracja nie znajdowała się w kolejnej parze nisz. 
Jak wynika z przeprowadzonych dotychczas badań porównawczych, wielką sień dekorowano w Toruniu głównie przedstawieniami religijnymi, przy czym - biorąc pod uwagę ich lokalizację w gwarnej przestrzeni domu, stanowiącej sferę bardzo różnych codziennych czynności - wątpliwe wydaje się przypisywanie im zadań dewocyjnych. Współtworząc domową ikonosferę, malowidła te mogły łączyć się z ars memorativa, także jako religijne napomnienie czy moralitet. Uwzględniając jednak recepcyjne funkcje przedniej części sieni, należy pamiętać, że adresatami ich przekazu byli nie tylko domownicy (często z różnych skoligaconych, zamieszkujących wspólnie rodzin i pokoleń) oraz zajmująca się gospodarstwem służba domowa, ale też goście, klienci, współpracownicy, partnerzy $\mathrm{w}$ interesach itd. Był to zatem przekaz otwarty, po części - publiczny. Można w nim widzieć nośny wyraz dbałości właścicieli o manifestację i potwierdzenie ich gorliwości religijnej, a zarazem uzewnętrznienie wyobrażeń, wpisanych w tzw. religijność miejską ${ }^{18}$. Jak się wydaje, obydwa nowo odkryte zabytki z wielkich sieni można interpretować z tej właśnie perspektywy.

Dekoracja dawnej sieni przy Rynku Staromiejskim 10 (obecnie w wydzielonym przedsionku kamienicy) umieszczona jest w niszy po stronie zachodniej (il. 3) ${ }^{19}$. Zachowany po prawej stronie na murze relikt

\footnotetext{
${ }^{18} \mathrm{Na}$ temat form i cech życia religijnego oraz zbiorowej religijnej mentalności, charakteryzującej mieszkańców wielkich miast, zob. H. Manikowska, Wstęp. Religijność miejska, [w:] Ecclesia et civitas. Kościót i życie religijne w mieście średniowiecznym, red. H. Manikowska, H. Zaremska, Warszawa 2002 („Colloquia Mediaevalia Varsoviensia" 3), s. 11-34, na temat religijności miejskiej por. B. Schwarz, Stadt und Kirche im Spätmittelalter, [w:] Stadt im Wandel. Kunst und Kultur des Bürgertums in Norddeutschland 1150-1650, Ausstellungskatalog, Hg. C. Meckseper, Bd. 4, Stuttgart-Bad Cannstadt 1985, s. 63-73. Zob. też osobną analizę życia religijnego w wielkich miastach pruskich z uwzględnieniem świadectw obrazowych: M. Jakubek-Raczkowska, 'Tu ergo flecte genua tua'. Sztuka a praktyka religijna świeckich $w$ diecezjach pruskich państwa zakonu krzyżackiego do połowy XV wieku, Pelplin 2014, s. 255-391; na temat religijnej mentalności mieszczan zwł. s. 273-284.

${ }^{19}$ Wymiary niszy: $3,75 \times 3,23 \mathrm{~m}$, gł. $0,12 \mathrm{~m}$; zachowany fragment polichromii: $1,89 \times 3,23 \mathrm{~m}$; powierzchnia ok. $6,5 \mathrm{~m}^{2}$. Nisza jest ujęta w szerokie sfazowane obramienie, udekorowane białą wicią roślinną z postrzępionych liści; bardzo zbliżony ornament zachował się we fryzie podstropowym świetlicy kamienicy narożnej przy ul. Świętego Ducha 12 - nie można wykluczyć wspólnego warsztatu, a przynajmniej tego samego czasu powstania.
} 


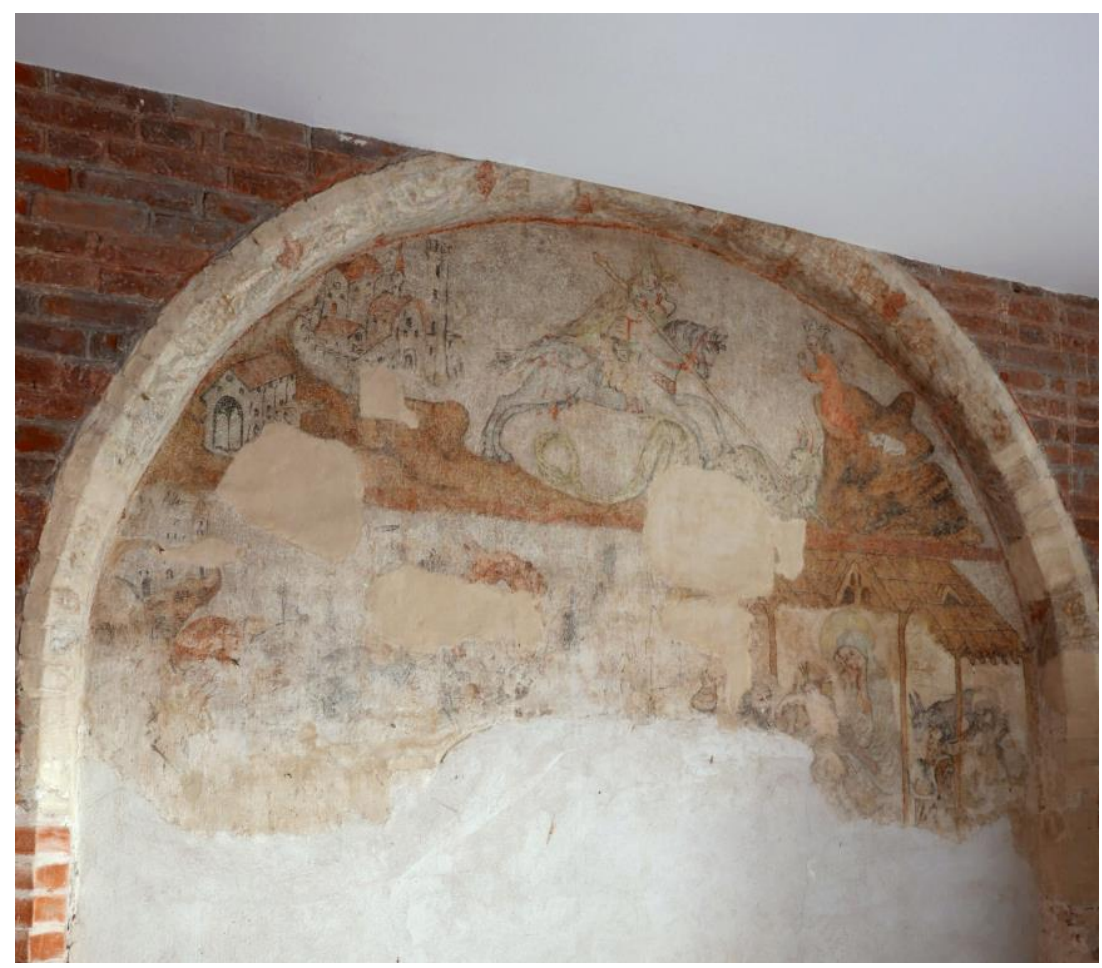

Il. 3. Toruń, kamienica przy Rynku Staromiejskim 10. Nisza po stronie zachodniej przedsionka (dawna wielka sień), 4. ćw. XIV w., fot. J. Raczkowski

bliżej nieokreślonej polichromii wskazuje, że cały system malarski mógł wychodzić poza jej obręb - zakres ten jest niestety zupełnie nieuchwytny. Z dawnego wystroju malarskiego niszy zachował się jedynie górny fragment $\mathrm{z}$ dwoma przedstawieniami religijnymi, zakomponowanymi w dwóch strefach (il. 4$)^{20}$. Stan zachowania warstw malarskich nie pozwala na pełną ocenę pierwotnego oddziaływania tego dzieła: plama barwna jest silnie przetarta, pierwotny koloryt i modelu-

${ }^{20}$ Pod względem rozwiązania kompozycyjnego malowidło znajduje jedną toruńską analogię - dekorację niszy przy ul. Szerokiej 16, której górną partię również wypełnia szeroko zakomponowane przedstawienie wielofiguralne (Pokłon Trzech Króli). 
nek światłocieniowy są dziś trudno uchwytne. Czytelny jest natomiast zarówno kładziony swobodnie rysunek przygotowawczy, jak i płynne kontury wykończeniowe o zróżnicowanej grubości i lekkości.

Całą powierzchnię podłucza archiwolty zajmuje scena Walki św. Jerzego ze smokiem. Jej kompozycja jest spiętrzona, dynamiczna, jakby rozedrgana; ujęta $\mathrm{w}$ widoku lekko $\mathrm{z}$ góry i silnie scentralizowana. Święty Jerzy w pełnym uzbrojeniu, galopujący na siwym koniu i przebijający włócznią wężowe ciało smoka (il. 5), ukazany jest na osi symetrii niszy; po prawej stronie na spiętrzonych skałkach klęczy drobna postać księżniczki, której towarzyszy biały baranek. Tło przedstawienia jest potraktowane pejzażowo, z zaznaczonymi elementami architektury - po lewej stronie ukazano ujęty perspektywicznie gródek okolony kolistą linią obwarowań z krenelażem i sumarycznie potraktowany młyn (?). Warto odnotować, że w sztuce państwa zakonnego w Prusach narracyjne przedstawienia tematu Walki św. Jerzego ze smokiem - wywodzące się ze świata dworskiej fantazji - należą raczej do rzadkości. W sferze świeckiej na przełomie XIV i XV w. wskazać można jeszcze tylko malowidło ścienne w świetlicy domu przy ul. Żeglarskiej $5 \mathrm{w}$ Toruniu; w przestrzeniach sakralnych do najciekawszych realizacji z tego czasu należą dwie rzeźbiarskie grupy - ze Starej Kościelnicy ${ }^{21}$ i z fary Mariackiej w Gdańsku ${ }^{22}$ (ta ostatnia uzupełniona około 1430 r. malowanym $\mathrm{w}$ tle pejzażem ${ }^{23}$ ). Toruński zabytek stanowi zatem ikonograficzną rzadkość na tle czternastowiecznej sztuki regionu ${ }^{24}$.

\footnotetext{
${ }^{21}$ Zachował się tylko fragment figury św. Jerzego, przechowywany w Muzeum Diecezjalnym w Pelplinie.

${ }^{22}$ Kaplica św. Jerzego. Nt. obu grup rzeźbiarskich zob. szczegółowo M. JakubekRaczkowska, Rzeźba gdańska przełomu XIV i XV wieku, Warszawa 2006, s. 59-65.

${ }^{23}$ J. Domasłowski, Malarstwo ścienne, s. 38.

${ }^{24}$ W końcu XV w. popularność narracyjnych wyobrażeń wzrosła. Przykładów dostarcza zarówno sztuka wielkich miast (grupa rzeźbiarska z Dworu Artusa w Gdańsku, relief ołtarzowy z Elbląga - dziś w Muzeum Narodowym w Gdańsku), jak i wsi (zob. malowidło w kościele par. w Niedźwiedzicy). Zob. A. Grabowska-Lysenko, Parafie wiejskie z obszaru Prus okiem historyka sztuki - problemy i dezyderaty badawcze na przykladzie kościoła pw. św. Jakuba w Niedźwiedzicy, [w:] Parafie w średniowiecznych Prusach w czasach Zakonu Niemieckiego od XIII do XVI w. („Ecclesia clerusque temporibus medii aevi” 4), red. R. Biskup, A. Radzimiński, Toruń 2015, s. 109-126, zwł. s. 124-126.
} 


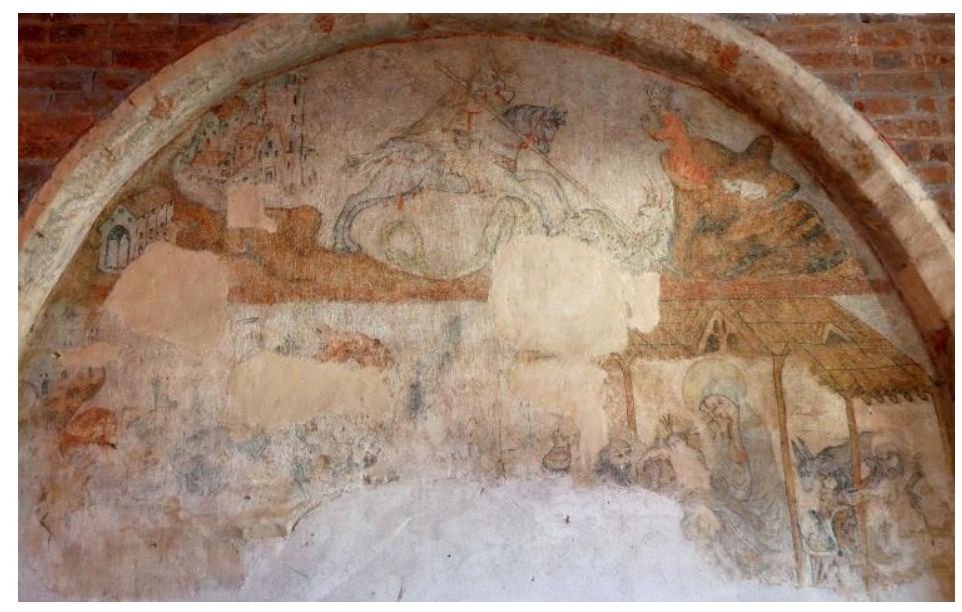

Il. 4. Toruń, kamienica przy Rynku Staromiejskim 10. Malowidło w niszy ściennej, Pokłon Trzech Króli, Walka św. Jerzego ze smokiem, 4. ćw. XIV w., fot. J. Raczkowski

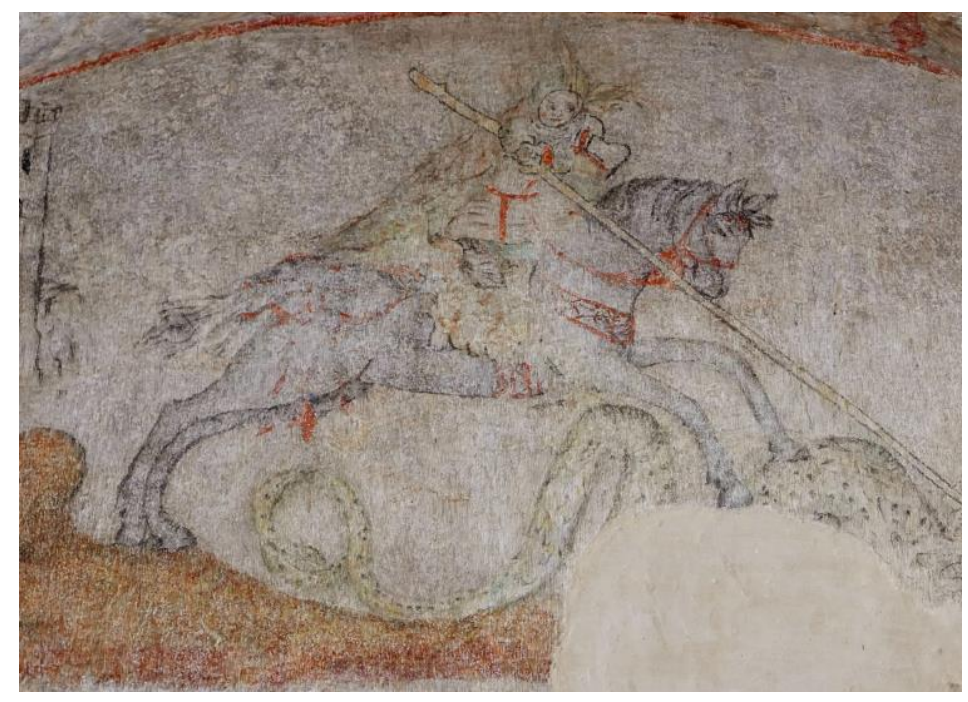

Il. 5. Toruń, kamienica przy Rynku Staromiejskim 10. Fragment Walki św. Jerzego ze smokiem, 4. ćw. XIV w., fot. J. Raczkowski 
Drugie z przedstawień w niszy ściennej przy Rynku Staromiejskim 10, umieszczone w wąskim pasie poniżej Walki św. Jerzego, to fragmentarycznie zachowany Pokłon Trzech Króli. Z całej tej sceny przetrwało tylko przedstawienie Świętej Rodziny (il. 6); pozostałe partie obrazu czytelne są jedynie dzięki drobnym pozostałościom (jak głowa jednego z mędrców, fragment atrybutu, fragmenty figur końskich po lewej stronie). Biorąc pod uwagę kształt pola obrazowego, przedstawienie musiało być zakomponowane kulisowo, a kolejne postaci tworzyły rodzaj prezentacyjnego szeregu. Zachowane relikty wskazują, że scena osadzona była na pejzażowym tle z elementami architektury i obejmowała: orszak konny po lewej stronie, trzech mędrców w centrum i stajenkę betlejemską po stronie prawej. Samo przedstawienie Pokłonu Trzech Króli (na ile można je rekonstruować w oparciu o zachowane fragmenty) nie wyróżniało się raczej na tle ikonografii tego czasu, natomiast wprowadzenie orszaku należy do rzadkości i może wyrażać predylekcję mieszczańskich odbiorców do atrakcyjnych wizualnie przedstawień o cechach arystokratycznych ${ }^{25}$. Po prawej stronie, na tle lekkiej drewnianej altany, krytej strzechą, ukazano Madonnę z Dzieciątkiem. Maria, scharakteryzowana jako młoda, wyidealizowana niewiasta o smukłej budowie ciała, spowita wraz z głową w błękitny płaszcz, siedzi wyprostowana, zwrócona w lewo, trzymając na kolanach nagie Dzieciątko, upozowane w dynamicznym, pełnym ekspresji układzie. Jezus przechyla się całym ciałem w stronę pierwszego z mędrców (zapewne klęczącego ${ }^{26}$ ), podając mu do ucałowania prawą rączkę; lewą najprawdopodobniej dotykał daru. Jak można wnioskować w oparciu

\footnotetext{
${ }^{25}$ Innym przykładem w Toruniu jest malowidło w dawnej wielkiej sieni kamienicy przy ul. Szerokiej 16.

${ }^{26} \mathrm{Z}$ postaci tej zachowała się tylko brodata głowa. Redakcja ikonograficzna, w której pierwszy z mędrców, scharakteryzowany jako najstarszy (często o długiej siwej brodzie), klęczy pokornie u stóp Madonny z Dzieciątkiem, a dwaj pozostali stoją, prezentując dary, upowszechniła się w ikonografii w 1. poł. XIV w.; w państwie zakonnym najstarszą jej realizacją jest scena w tympanonie portalu północnego kaplicy św. Anny w Malborku. W wariancie tym głowa klęczącego mędrca jest odkryta (jak na omawianym malowidle), a korona - złożona na ziemi; Dzieciątko zwykle nawiązuje z nim kontakt, błogosławiąc lub sięgając po dar; por. inne przykłady, jak malowidło w sieni przy ul. Szerokiej $16 \mathrm{w}$ Toruniu lub pruskie rzeźby ołtarzowe z końca XIV w. (relief z Pietrzwałdu ze zbiorów Muzeum Warmii i Mazur w Olsztynie, z Pietrzwałdu k. Sztu-
} 


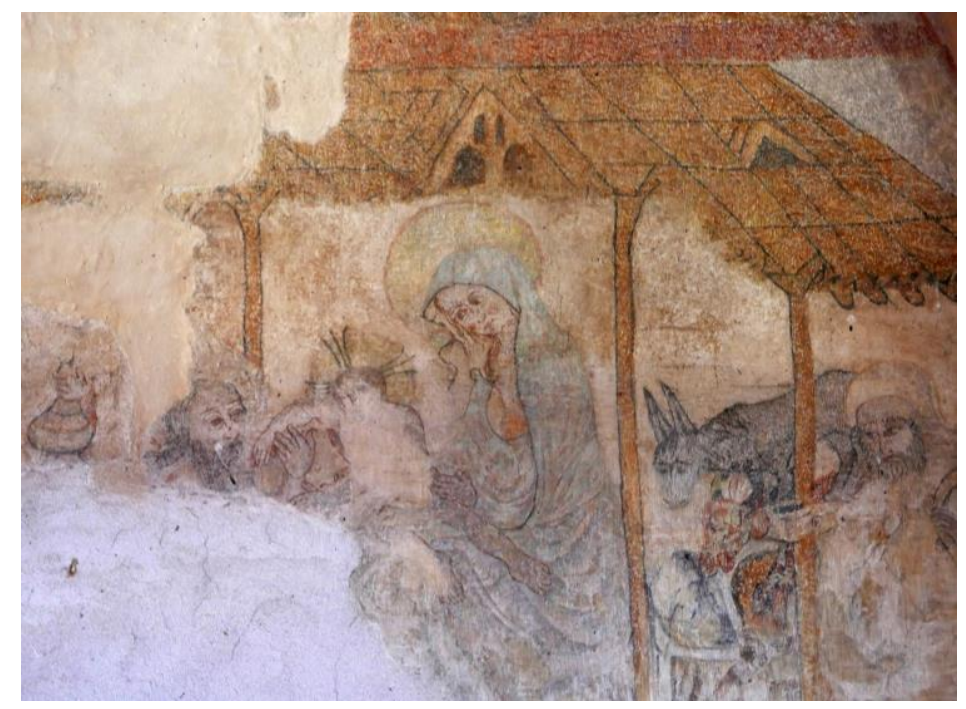

Il. 6. Toruń, kamienica przy Rynku Staromiejskim 10.

Fragment Pokłonu Trzech Króli, 4. ćw. XIV w., fot. J. Raczkowski

o analogie ikonograficzne, pozostali królowie najpewniej ukazani byli en pied, choć $\mathrm{z}$ całej grupy zachował się tylko fragment daru $\mathrm{w}$ ręce drugiego z mędrców. Bliżej prawej krawędzi niszy ukazano postać św. Józefa $^{27}$, na drugim planie widnieją zwierzęta - wół i osioł. Kompozycyjne wyizolowanie św. Józefa, jego poza i czytelny na twarzy wyraz zafrasowania, nieprzystające do podniosłego charakteru całej sceny, to

mu ze zbiorów Muzeum Narodowego w Warszawie lub z Łabędnika). Wśród XIVwiecznych przedstawień tej sceny, znanych w terenów państwa zakonnego w Prusach, gest ucałowania dłoni Dzieciątka przez mędrca znajduje analogię tylko w przedstawieniu zachowanym w kamienicy przy ul. Żeglarskiej 5 w Toruniu (choć w tym ostatnim nie jest on tak bezpośredni - mędrzec ujmuje dłoń Dzieciątka, ale nie przykłada do niej ust).

${ }^{27} \mathrm{~W}$ przytoczonych wyżej przykładach rzeźbiarskich scena ograniczona jest wyłącznie do dogmatycznej treści Epifanii (tronująca Maria z Dzieciątkiem i trzej mędrcy). Wyobrażenie św. Józefa towarzyszy rozbudowanym przedstawieniom narracyjnym, znanym z malarstwa ściennego (np. w kamienicach mieszczańskich Torunia przy ul. Szerokiej 16 i przy ul. Żeglarskiej 5). 
typowa dla sztuki późnego średniowiecza charakterystyka tej postaci, nadająca jej cech nieco ludowych ${ }^{28}$. Nie wiadomo, jak rozwiązana była kompozycja malowidła w dolnej partii niszy. Nie ma podstaw, by rozstrzygnąć, czy całość pola wypełniały kolejne sceny figuralne w układach strefowych, czy też dolną strefę zdobiły iluzjonistycznie malowane kotary lub ornament patronowy ${ }^{29}$.

Oparcie kompozycji figuralnej na miękkich łukach (odcinkowych i pełnych), stylizacja manierycznie giętkiej linii konturu, typy postaci oraz ich pozy, gesty i cechy fizjonomiczne (twarze ujmowane en trois quarts, o dużych nosach i oczach okonturowanych charakterystycznymi obwódkami) wskazują na czeskie (praskie) źródła stylu malowidła $z$ lat około 1360-1380. Jest ono być może transpozycją małoformatowych wzorów miniatorskich lub wzorników rysunkowych, podobnych do przypisywanych mistrzowi Teodorykowi z Pragi rysunków piórkiem, przechowywanych w Universitätsbibliothek w Erlangen-Norymberdze ${ }^{30}$. Nie byłby to jedyny znany w malarstwie Torunia przykład sięgnięcia do czeskich pierwowzorów ${ }^{31}$, warto jednak odnotować, że płynność

${ }^{28}$ Zwrócił na to uwagę G. Jaritz, Bildquellen zur mittelalterlichen Volksfrömmigkeit, [w:] Volksreligion im hohen und späten Mittelalter, Hg. P. Dinzelbacher, D. R. Bauer (,Quellen und Forschungen aus dem Gebiet der Geschichte” NF13), PaderbornMünchen-Wien-Zürich 1990, s. 195-219, zwł. s. 213. Jego zdaniem, plebejska - niekiedy nawet humorystyczna - charakterystyka św. Józefa w scenach betlejemskich to typowy przykład dążenia do uzyskania emocjonalnego wyrazu, bliskiego prostym odbiorcom, jakie naznaczyło sztukę późnego średniowiecza.

${ }^{29}$ Rozwiązanie takie jest znane z dekoracji świetlic domów toruńskich, o czym jeszcze poniżej. Spośród znanych z Torunia dekoracji figuralnych w niszach ściennych o zbliżonej formie, zarówno (zatynkowane) malowidło w domu przy ul. Żeglarskiej 17/19, jak i scenki w izbie domu przy Piekarach 37, łączą partie figuralne w podłuczu niszy z umieszczonymi poniżej kotarami.

${ }^{30}$ Sygn. H62/B 1, H62/B 2; zob. http://digital.bib-bvb.de/view/bvbmets/viewer.0. 6.1.jsp?folder_id $=0 \& d v s=1509871430468 \sim 779 \&$ pid $=3005019 \&$ locale $=$ de $\&$ usePid $1=t$ rue\&usePid2=true oraz http://digital.bib-bvb.de/view/bvbmets/viewer.0.6.1.jsp?folder_ $\mathrm{id}=0 \&$ dvs=1509871465029 326\&pid=3011862\&locale=de\&usePid $1=$ true \&usePid2= true (dostęp na dzień 3 XI 2017).

${ }^{31}$ Wpływy praskie z kręgu Mistrza Teodoryka z Pragi i Mistrza Emaus dominowały w 2. poł. XIV w. w malarstwie całego państwa zakonnego. Wśród ważniejszych realizacji malarskich Torunia znajdują się z całą pewnością młodsze kwatery Poliptyku Toruńskiego (1380-1400), a także malowidła z kamienic przy ul. Królowej Jadwigi 9 (ok. 1380), Żeglarskiej 5 (ok. 1390-1400) i Żeglarskiej 10 (4. ćw. XIV w.) oraz przed- 
linii, swoboda kompozycji i mnogość detali pozwalają zaliczyć je do grona najlepszych bohemizujących realizacji w całym gotyckim malarstwie ściennym w przestrzeniach świeckich Torunia; dzieło można datować na ostatnią ćwierć XIV w.

Treści ideowe tej kompozycji wpisują się z jednej strony w potrzebę mieszczańskiej ostentacji, z drugiej - w nośny sposób dokumentują sferę religijnej mentalności. Wybór tematów (malownicza Walka św. Jerzego i pierwotnie zapewne bardzo dekoracyjny orszak Trzech Kró$\mathrm{li}^{32}$ ) może wskazywać na arystokratyzujący gust i ambicje zleceniodawców. Oba przedstawienia mieszczą się w ramach tradycyjnych mieszczańskich kultów i łączą się z troską o pomyślność doczesną, dobrą śmierć i przyszłe zbawienie. Zarówno św. Jerzy, jak i trzej mędrcy, byli czczeni w średniowieczu jako święci wspomożyciele, przy czym Trzej Królowie, opiekunowie podróżnych, byli szczególnie bliscy mobilnemu kupiectwu ${ }^{33}$. Pokłon Trzech Króli obrazował wydarzenie ewangeliczne i jedno z najważniejszych świąt roku liturgicznego (Epifanię), ale miał też dodatkowe konotacje: eksponował idealną wizję Świętej Rodziny, w tym św. Józefa, czczonego jako patrona dobrej śmierci ${ }^{34}$. Wyobrażenie pokornego hołdu przed obliczem Marii i Chrystusa należało także do najbardziej popularnych obrazów imitatio pietatis (sugestywnych, wizualnych modeli pobożności) adresowanych do

stawienie Męczeństwa św. Katarzyny w prezbiterium kościoła świętojańskiego (ok. 1370-1380).

${ }^{32}$ Pokłon Trzech Króli ma swoje analogie w dekoracjach innych toruńskich kamienic. Do nieco lepiej zachowanych przykładów należy kompozycja z dawnej wielkiej sieni domu przy ul. Szerokiej 16 oraz w dawnej świetlicy kamienicy przy ul. Żeglarskiej 5. Oba te malowidła wyraźnie wskazują na zamiłowanie do dworskiego kostiumu oraz drobiazgowo oddawanych detali i atrybutów; na ul. Szerokiej $16 \mathrm{w}$ tle pojawiają się scenki łowieckie. Pokłon Trzech Króli ukazano również w dawnej świetlicy przy Królowej Jadwigi 9.

${ }^{33}$ J. Kaliszuk, Mędrcy ze Wschodu. Legenda i kult Trzech Króli w średniowiecznej Polsce, Warszawa 2005, s. 129 i s. 133 - patronaty Mędrców (obrońców przed nagłą i niespodziewaną śmiercią, wspomożycieli w przypadku zagrożeń i opiekunów podróżnych) predestynowały ich wręcz do roli patronów zawodu kupieckiego.

${ }^{34}$ A. Dülberg, Die sogenannte Schatzkammer im Kaufmannshaus Untermarkt 5 in Görlitz. Zur Ikonographie der illusionistischen Wandmalereien vom Anfang des 16. Jahrhunderts, Marburger Jahrbuch für Kunstwissenschaft 28 (2001), s. 133-158, zwł. s. 141. 
świeckich $^{35}$. Choć $\mathrm{w}$ domniemanym czasie wykonania polichromii kamienica nie należała do żadnego z ważniejszych rodów miejskiej elity władzy $^{36}$, zarówno lokalizacja samej działki, jak i szlachetna w formie i treści dekoracja malarska sieni świadczą o prestiżu właścicieli domu.

Jeszcze mniej można powiedzieć o właścicielach kamienicy przy ul. Kopernika 6, w której również w dawnej przestrzeni wielkiej sieni odkryto $\mathrm{w}$ ostatnich latach fragment interesującego wystroju figuralnego. Z całą pewnością i tu lokalizacja samego budynku świadczy o wysokim statusie społecznym i majątkowym mieszkańców, a program ideowy wystroju - o ich głębokiej identyfikacji ze wspólnotą parafii staromiejskiej. Szczątki malowidła, powstałego najpewniej na przełomie XIV i XV w., zachowały się w płytkiej, ujętej w bogato profilowane obramienie niszy ściennej na zachodniej ścianie dawnego traktu frontowego (il. 7) ${ }^{37}$. I tu polichromia zajmuje tylko górną partię niszy, zachowana jest fragmentarycznie (z rozległymi ubytkami), a jej warstwa malarska pozbawiona jest najprawdopodobniej powierzchniowego wykończenia - modelunku i detali. Inaczej niż w domu przy Rynku Staromiejskim 10, kompozycja niszy pomyślana jest jako asystencyjna prezentacja trzech postaci świętych, umieszczonych na neutralnym, ciemnobrązowym tle, zdobionym białymi kwiatkami ${ }^{38}$. W centrum, na osi kompozycji pomyślanej w duchu amor vacui, znajdowała się niegdyś

\footnotetext{
${ }^{35}$ Scena Epifanii ukazywała Dzieciątko - Słowo Wcielone - jako przedmiot czci (adoranda natalitia), przedstawiając jednocześnie jego ekspresyjną adorację przez Mędrców. Obraz taki mógł mieć funkcję apelu o naśladowanie pokornej wewnętrznej postawy religijnej i zewnętrznego gestu adoracji. Szczegółowo na różnych przykładach problem ten przeanalizował F. O. Büttner, Imitatio Pietatis. Motive der christlichen Ikonographie als Modelle zur Verähnlichung, Berlin 1983, s. 19-33. O motywach imitatio pietatis na przykładach pruskich: M. Jakubek-Raczkowska, op. cit., s. 177-178.

${ }^{36}$ Pod koniec XIV w. dom był w rękach rodziny Grosse - w 1394 r. zamieszkiwali w nim Zofia (Soffke) Grossynne, wdowa po Hermanie, jego syn z pierwszego małżeństwa Mikołaj i nieznany z imienia syn z drugiego małżeństwa, zob. Księgi szosu i wykazy obciążeń mieszkańców Starego Miasta Torunia z lat 1394-1435, wyd. K. Mikulski, J. Tandecki, A. Czacharowski („Źródła do dziejów średniowiecznego Torunia” 1), Toruń 2002, s. 21, przyp. 333 oraz 334.

${ }^{37}$ Wymiary niszy 1,9 x 2,72 m; zachowany fragment malowidła: 1,09 x 2,72 m.

${ }^{38}$ Pod tym względem dzieło jest nieco zbliżone do dekoracji wielkiej sieni w kamienicy przy ul. Królowej Jadwigi 9, choć zastosowany tam system - odrębne tła i obramienia dla przedstawień - jest odmienny.
} 


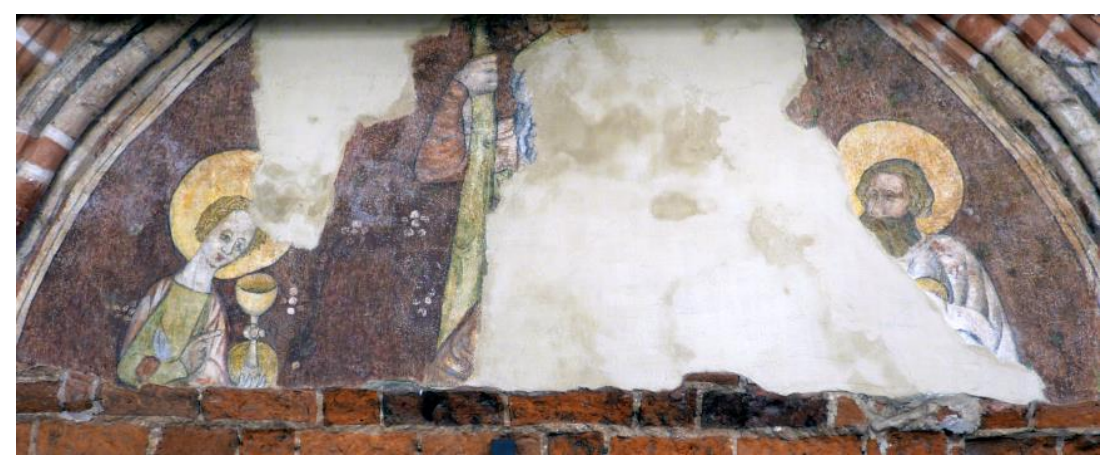

Il. 7. Toruń, kamienica przy ul. Kopernika 6. Malowidło w niszy ściennej w dawnej wielkiej sieni, koniec XIV w., fot. J. Raczkowski

figura św. Krzysztofa, znacznie powiększona w stosunku do pozostałych $^{39}$. Po jego bokach widniały wizerunki św. Jana Ewangelisty (po lewej stronie) oraz św. Jana Chrzciciela (po stronie prawej). Do naszych czasów najlepiej zachowała się półpostać młodzieńczego św. Jana Ewangelisty (il. 8); pozostałe figury przetrwały w stanie szczątkowym $^{40}$; można się jedynie domyślać, że cała trójosiowa, oszczędna kompozycja nosiła cechy sakralnego monumentalizmu, a zarazem sądząc po intensywności kolorystyki i detalu - dużej dekoracyjności. Prezentacyjne pozy, wyolbrzymienie nimbów wokół głów świętych Janów, gest św. Jana Ewangelisty, który wskazuje na kielich eucharystyczny i skłania ku niemu głowę, decydują o dużej sugestywności tej kompozycji. Jej szczególna tematyka znajduje swe antecedencje w znacz-

\footnotetext{
${ }^{39}$ Jest to zgodne z tradycją ikonograficzną i legendą, według której św. Krzysztof uchodził za człowieka o olbrzymich rozmiarach (trzykrotnie przewyższających przeciętne) i wielkiej sile, zob. G. Benker, Christophorus. Patron der Schiffer, Fuhrleute und Kraftfahrer. Legende, Verehrung, Symbol, München 1975, s. 54; w sztuce wyobrażenia św. Krzysztofa są często wyolbrzymione.

${ }^{40} \mathrm{Z}$ postaci św. Jana Chrzciciela przetrwały tylko głowa okolona kolistym nimbem, fragment lewego ramienia okrytego białym płaszczem oraz fragment postaci baranka, którego zapewne święty podtrzymywał na księdze, niesionej w lewej ręce. $\mathrm{Z}$ wyobrażenia św. Krzysztofa czytelne są kontur siwej brody oraz prawa ręka oparta na wysokim, zielonym kosturze.
} 


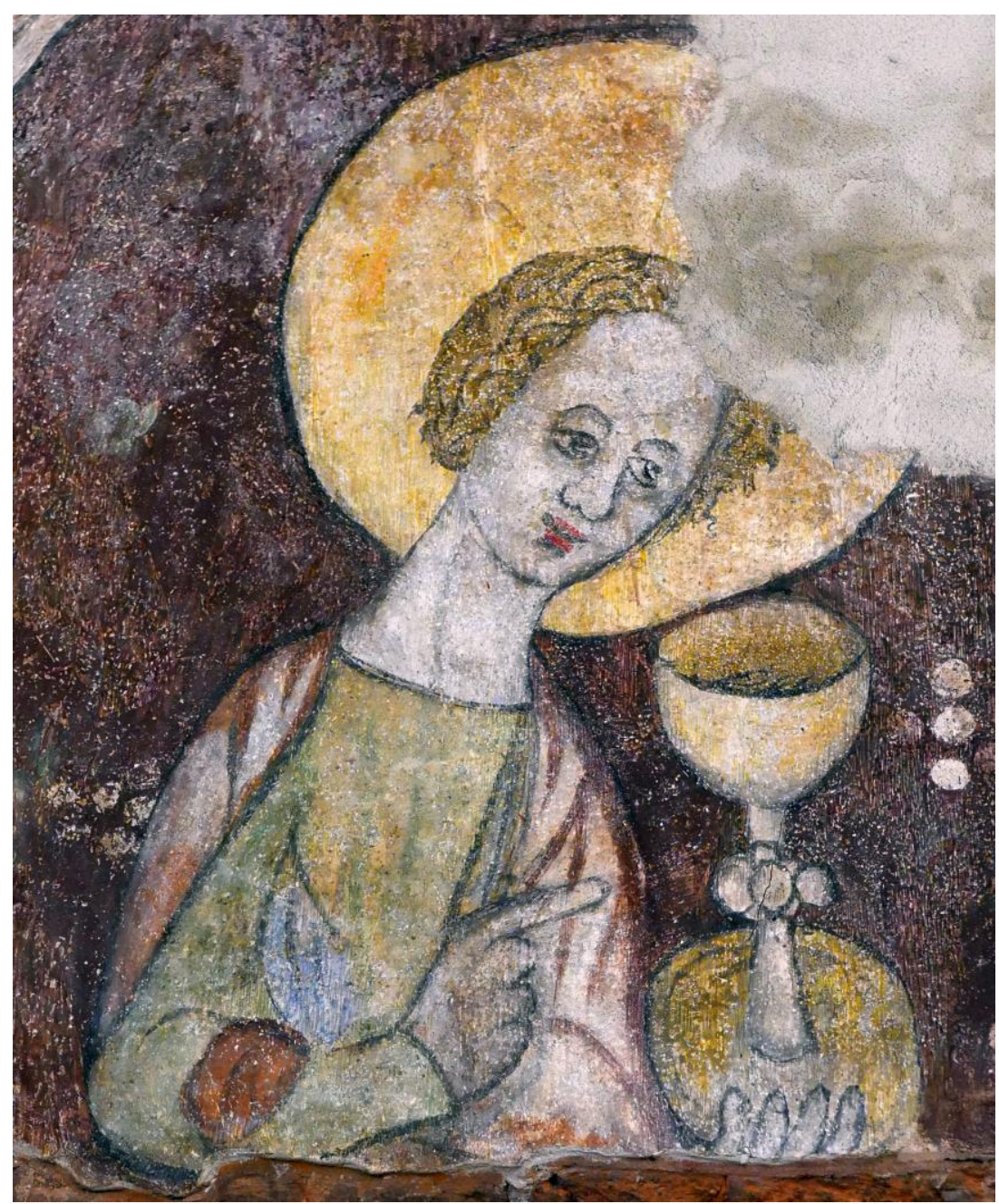

Il. 8. Toruń, kamienica przy ul. Kopernika 6. Malowidło w niszy ściennej w dawnej wielkiej sieni - fragment, św. Jan Ewangelista, koniec XIV w., fot. J. Raczkowski 
nie wcześniejszym (połowa XIV w.) malowidle z kamienicy przy ul. Żeglarskiej $17 / 19^{41}$. W obu przypadkach bardzo wyraźnie zaakcentowany został kult obu świętych Janów - zapewne w bezpośredniej łączności z kultem patronalnym parafii staromiejskiej. W przypadku starszego malowidła święci patroni towarzyszą Chrystusowi reprezentowanemu przez Veraikon. W domu przy ul. Kopernika 6 osią przedstawienia jest natomiast wizerunek św. Krzysztofa, w późnośredniowiecznej mentalności traktowany jako rodzaj apotropaicznej ochrony przed nieszczęściami oraz nagłą i niespodziewaną śmiercią ${ }^{42}$ (zwłaszcza w podróży), co tłumaczy jego obecność w sieni.

Pod względem artystycznym malowidło wydaje się bardzo zbliżone do bohemizujących polichromii, zachowanych w świetlicy pobliskiego domu przy ul. Żeglarskiej 5. Wyraźne analogie w tamtejszej figurze archanioła ze sceny Zwiastowania znajdują budowa postaci św. Jana Ewangelisty - o dużej głowie, długiej, szerokiej szyi i wąskich ramionach, a także rysy jego młodzieńczej twarzy - o wydatnym nosie, charakterystycznych oczach, dużych, blisko osadzonych, ujętych w kolistą obwódkę, oraz wydatnych choć wąskich ustach, malowanych intensywną czerwienią. Malowidła z Żeglarskiej 5 wykazują z kolei wyraźne związki $\mathrm{z}$ niektórymi tablicami Poliptyku Toruńskiego ${ }^{43}$. Nowo odkryte dzieło pozwala zatem na pogłębienie analiz na temat działalności i wzajemnych relacji warsztatów malarskich, czynnych w Toruniu w okresie późnego średniowiecza.

Dwa pozostałe odkrycia pochodzą z innego typu wnętrz. Zachowały się na ścianach tzw. świetlic - przestronnych pomieszczeń, zlokali-

\footnotetext{
${ }^{41}$ J. Domasłowski, Malowidta ścienne, s. 39-40; tenże, Malarstwo ścienne, s. 13-14.

${ }^{42}$ Wiara w siłę ochronną św. Krzysztofa łączyła się w średniowieczu z zabobonnym przekonaniem o mocy sprawczej spojrzenia na jego wizerunek (A. L. Mayer, Die heilbringende Schau in Sitte und Kult, [w:] Beiträge zur Geschichte des alten Mönchtums und des Benediktinerordens, Hg. I. Herwegen, Münster 1938, s. 234-262, zwł. s. 253). Przeświadczenie to było krytykowane przez Kościół (G. Benker, op. cit., s. 153), ale cześć św. Krzysztofa jako wspomożyciela i patrona dobrej śmierci była w późnym średniowieczu promowana także w ramach oficjalnej religijności, co thumaczy wielką popularność wizerunków tego świętego zarówno w przestrzeniach liturgicznych, jak i w sferze prywatnej.

${ }^{43}$ Por. J. Raczkowski, Poliptyk Toruński. Studium zabytkoznawczo-konserwatorskie, Toruń 2016, s. 137-159.
} 
zowanych na drugiej kondygnacji w tylnym trakcie domów. Ich funkcje bywały różne i zmienne; stanowiły one najpewniej miejsce przebywania większej grupy domowników. W kamienicach kupieckich mogły grać rolę reprezentacyjną - służyć przyjmowaniu gości, przedkładaniu towaru znamienitym klientom, zawieraniu umów ${ }^{44}$. Stąd też nadawano im ekskluzywny charakter ${ }^{45}$ : były ogrzewane kominkiem lub piecem, kryte stropami o profilowanych belkach i wykładane ceramicznym pawimentem; w ich ściany wprowadzano nisze szafkowe, wnęki umywalkowe ${ }^{46}$, czasem zdobiono je płytkimi blendami (podobnie jak w wielkiej sieni). Podziały tego typu warunkowały zwykle kompozycyjny system malowideł. Mobiliarz świetlic był zmienny zależał od przypisanych im funkcji.

Bardzo niewiele można obecnie powiedzieć o pierwotnym wyglądzie świetlicy w domu przy ul. Różanej 1, który w średniowieczu stanowił gniazdo rodowe znamienitej toruńskiej rodziny patrycjuszowskiej vom Nichte ${ }^{47}$. Wnętrze to zostało bardzo silnie przekształcone: nie pozostały $\mathrm{w}$ nim żadne ślady po urządzeniu grzewczym, podziałach ścian, wnękach, niszach i innych. Jedynym świadectwem dawnej prestiżowej rangi pomieszczenia jest pozostałość po wystroju malarskim - pionowy fragment pierwotnie trójstrefowej dekoracji (il. 9), najpewniej świadek systemu, obejmującego niegdyś całe wnętrze. Trudno dziś określić jego pierwotną wysokość, gdyż poziom pomieszczenia został całkowicie zmieniony w stosunku do poziomu pierwotnego; strefa górna - fryz wieńczący - nie daje się w pełni zrekonstruować (zachowany fragment to dwa barwne gładkie segmenty, które niosły być może dekorację ornamentalną). W dolnej części ściany, zgod-

\footnotetext{
${ }^{44}$ Tę funkcję akcentuje K. Górski, Dom i środowisko rodzinne Mikołaja Koperni$k a$, Toruń 1968, s. 27.

${ }^{45}$ Zob. m.in. E. Gąsiorowski, op. cit., s. 84; por. też G. Ditmar-Trauth, op. cit., s. 47-48 (z odniesieniem do niemieckich źródeł dotyczących nazewnictwa).

${ }^{46}$ Zob. osobno Z. Nawrocki, Kilka nie od razu rozpoznanych elementów wyposażenia kamienic toruńskich, [w:] Stare i nowe dziedzictwo Torunia, red. J. Raczkowski, (,Studia i materiały z dziedzictwa kulturowego Torunia i regionu” 1, red. J. Raczkowski), Toruń 2013, s. 124-129.

${ }^{47}$ W księdze szosu z 1394 r. cały odcinek ul. Św. Ducha pomiędzy Różaną i Kopernika nazywano „Circumque Petro de Nichte”: Ksieggi szosu, s. 22.
} 


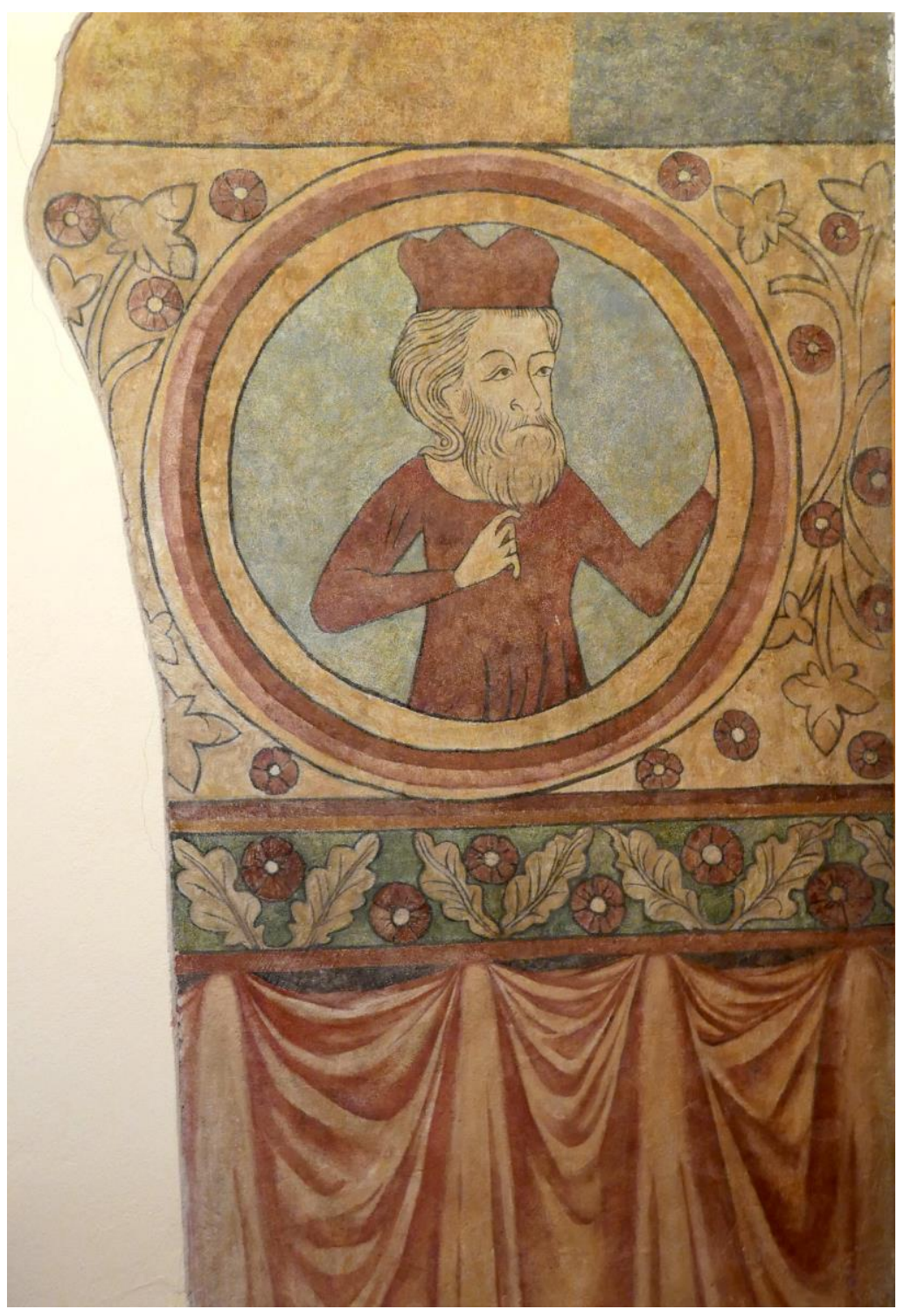

Il. 9. Toruń, kamienica przy ul. Różanej 1. Malowidło w pomieszczeniu II kondygnacji (dawna świetlica), ok. 1360, fot. J. Raczkowski 
nie $\mathrm{z}$ zasadą stosowaną powszechnie $\mathrm{w}$ bogatych wnętrzach mieszkalnych średniowiecznej Europy, wymalowano rozwieszone na drążku kotary o cechach iluzjonistycznych ${ }^{48}$. Mogły one stanowić zastępczą imitację rzeczywistych tkanin; prawdopodobne jest też, że w chłodniejszej porze tę część ściany faktycznie docieplano oponami. W środkowym pasie dekoracji, wydzielonym od dołu płaskim kwiatowym fryzem, zachował się pojedynczy medalion o wielobarwnym obramieniu, ukazujący półpostać brodatego mężczyzny na neutralnym błękitnym tle - najpewniej wyobrażenie proroka ${ }^{49}$. Medalion osadzony jest w polu usianym drobnymi wielolistnymi rozetkami i flankowany syntetycznymi gałązkami dębu. Można zakładać, że ciąg takich medalionów (oddzielonych od siebie stylizowaną roślinnością) obiegał całe pomieszczenie. Skojarzenia $\mathrm{z}$ podobnymi $\mathrm{w}$ formie i kompozycji medalionami ze sklepienia prezbiterium w kościele św. Jana Chrzciciela i św. Jana Ewangelisty, z podłucza w zachodnim przęśle nawy południowej w kościele św. Jakuba czy z zacheuszkami w zakrystii kościoła NMP w Toruniu nie są przypadkowe. Malowidło z ul. Różanej 1 jest jednym z najstarszych znanych przykładów sakralizacji wnętrza prywatnego przez bezpośrednie nawiązanie do wystroju kościelnego, a zarazem jednym z najstarszych zabytków polichromii wnętrza mieszczańskiego w ogóle, znacząco uzupełnia zatem wiedzę o początkach kształtowania się lokalnej twórczości malarskiej.

Ze względu na stopień reintegracji warstw malarskich podczas prac konserwatorskich ${ }^{50}$ forma dzieła trudno poddaje się szczegółowej analizie. Mimo to można przypuszczać, że wpisuje się ono prawdopodob-

\footnotetext{
${ }^{48}$ Dekoracje kotarami pojawiają się w najsłynniejszych wnętrzach pałacowych zachodniej Europy, np. w sypialni papieskiej w rezydencji w Awinionie i pałacach we Florencji (zob. M. Dachs, Zur ornamentalen Freskendekoration des Florentiner Wohnhauses im späten 14. Jahrhunderts, Mitteilungen des Kunsthistorischen Instituts in Florenz 37/1 (1993), s. 71-129). W polichromiach kamienic toruńskich zachowało się kilka innych przykładów tego systemu, który stosowano w dekoracji świetlic oraz izb mieszkalnych aż do początku XVI w. (np. w domach przy Wielkich Garbarach 7 i Szczytnej 15).

${ }^{49}$ Postać najpewniej przytrzymywała niezachowaną do dziś banderolę.

${ }^{50}$ Malowidło jest na całej powierzchni scalone za pomocą punktowania, a jego partie boczne zostały w pełni zrekonstruowane. Por. fotografie sprzed konserwacji i restauracji: A. Błażejewska, E. Pilecka, Sztuka średniowieczna, il. 121.
} 
nie w oeuvre warsztatu, czynnego przy wystroju zachodniej partii kościoła św. Jakuba, którego dziełem było też najpewniej malowidło z kamienicy przy ul. Żeglarskiej $17 / 19^{51}$, znane dziś jedynie $\mathrm{z}$ archiwalnych fotografii i przerysu. Wskazuje na to ogólny typ wyobrażenia postaci ludzkiej, archaizująca fizjonomia, silny linearyzm oraz płaski modelunek, przełamany tylko w partii kotar, które malowane są za pomocą szerokich smug czerwieni, dających efekt pewnego iluzjonizmu.

Niezwykle wartościowy dla rozpoznania wystrojów mieszczańskich i dla ogólnej wizji dynamiki artystycznej Torunia, a także potrzeb i gustów miejskich zleceniodawców jest wreszcie zabytek, odkryty w 2016 r. przy okazji prac remontowo-adaptacyjnych prowadzonych w kamienicy przy ul. Żeglarskiej 16. Fragmenty średniowiecznej polichromii ujawniono tam pod dziewiętnastowiecznymi tynkami na ścianach dawnej świetlicy, z której pierwotnego kształtu przetrwały też malowane belki konstrukcyjne ściany (pierwotnie zapewne w całości była to budowla szachulcowa) oraz nisze ścienne i wnęka po kominku. Kamienica przy ul. Żeglarskiej 16 (budynek narożny naprzeciw kościoła parafialnego Starego Miasta) stanowiła własność rodu Reussów - jednej z najznamienitszych rodzin patrycjuszowskich średniowiecznego Torunia, osiadłej w mieście od początku XIV w. W $1394 \mathrm{r}^{52}$, w przypuszczalnym okresie powstania malowideł, dom pozostawał w rękach wdowy po protoplaście drugiej linii Reussów, Łukaszu ${ }^{53}$, oraz jego synów: Albrechta (rajcy i kupca prowadzącego handel dalekosiężny ${ }^{54}$ ), Jakuba ${ }^{55}$ (rajcy i ławnika) oraz Henryka ${ }^{56}$. Była to zatem własność mieszczańskich elit. Polichromie zachowane $\mathrm{w}$ reprezentacyjnej świetlicy tego domostwa stanowią ikonograficzny unikat: integrują dwa wątki, całkiem od siebie niezależne i rzadko spotykane we wnętrzach prywatnych.

\footnotetext{
${ }^{51} \mathrm{Na}$ te związki zwrócił uwagę J. Domasłowski, Malarstwo ścienne, s. 39.

${ }^{52}$ Ksiegi szosu, s. 57.

${ }^{53} \mathrm{Na}$ temat kariery Łukasza Reussa zob.: K. Mikulski, K. Kopiński, Herbarz patrycjatu toruńskiego, t. 1, Toruń 2008, s. 171-172.

${ }^{54}$ Ibid., s. 172-173; w wykazach urzędników miejskich Torunia: R. Czaja, Urzędnicy miejscy Torunia. Spisy, Część I: do roku 1454, Toruń 1999, nr 458, s. 137, nr 217, s. 90.

${ }^{55}$ K. Mikulski, K. Kopiński, op. cit., s. 173-175; w wykazach urzędników miejskich Torunia: zob. R. Czaja, op. cit., nr 477, s. 137; nr 244, s. 92.

${ }^{56}$ K. Mikulski, K. Kopiński, op. cit., s. 175.
} 
Całkowity zasięg dekoracji malarskiej nie jest już uchwytny - wydaje się, że poziom pomieszczenia został wtórnie podwyższony o około $70 \mathrm{~cm}^{57}$. Wystrój malarski oparto na systemie trójstrefowym, ze wspólną dla całego pomieszczenia strefą cokołową zdobioną ornamentem patronowym ${ }^{58} \mathrm{i}$ wspólnym fryzem wieńczącym w formie iluzjonistycznie potraktowanego krenelażu. Rozwiązania kompozycji figuralnych na obu ścianach świetlicy znacznie się różnią. Na ścianie zachodniej widnieje fragment cyklu Dziewięciu Bohaterów, który swą kontynuację miał najpewniej także na ścianie północnej. Zachowały się cztery $z$ dziewięciu postaci (il. 10) ${ }^{59}$ - naturalnej wielkości, ujęte frontalnie en plein pied, w pełnym uzbrojeniu, z mieczami i tarczami $\mathrm{w}$ dłoniach, ustawione w izokefalicznym szeregu i opatrzone biegnącym $\mathrm{u}$ dołu pasem minuskułowych dwuwersowych inskrypcji (już nieczytelnych). Obecność tego tematu w reprezentacyjnej świetlicy ma niebagatelne znaczenie dla oceny samoświadomości i ambicji rodu Reussów, a szerzej - patrycjatu toruńskiego. Obok niezachowanej dekoracji na zamku krzyżackim w Lochstedt ${ }^{60}$ jest to jedna $\mathrm{z}$ dwóch znanych realizacji tego tematu na terenie państwa zakonnego, a zarazem - dwóch najstarszych w monumentalnym malarstwie na północy. Cykle takie wiązały się zdecydowanie $z$ kręgiem symboliki rycerskiej i były adaptowane przez komuny miejskie do autoprezentacji w przestrzeni publicznej $^{61}$. Wybór tego tematu dowodzi zatem wysokiej formacji inte-

\footnotetext{
${ }^{57}$ Obecna rozpiętość dekoracji malarskiej wynosi 3,6 m wysokości.

${ }^{58}$ Romboidalna siatka geometryczna z motywami o cechach heraldycznych (w ukośnych układach naprzemiennie: czerwone orły i błękitne lwy).

${ }^{59}$ Obecnie polichromia obejmuje następujące przedstawienia (licząc od południa): Juda Machabeusz (tarcza z czarnym smokiem w białym polu), Jozue (orzeł na tle szachownicy), król Dawid (tarcza z harfą w srebrnym polu) oraz król Artur (tarcza z trzema złotymi koronami na białym tle).

${ }^{60} \mathrm{~J}$. Domasłowski, Uwagi o programach ideowych, s. 150-152; tenże, Malarstwo ścienne, s. 31-32; C. Meckseper, Wandmalerei im funktionalen, s. 265-266.

${ }^{61} \mathrm{Na}$ północ od Alp pierwsze przykłady aneksji tematu sięgają jeszcze pierwszej połowy XIV w. (np. wystrój rzeźbiarski Sali Hanzy w ratuszu kolońskim, zob.: H. Schroeder, Der Topos der Nine Worthies in Literatur und bildender Kunst, Göttingen 1971, s. 113-114) i mnożą się pod koniec stulecia. Dobrym przykładem jest dekoracja Schönen Brunnen w Norymberdze $z$ lat 90 . XIV w., a także niezachowane posągi w ratuszu hamburskim datowane hipotetycznie na pocz. XV w.: H. Schroeder, op. cit.,
} 


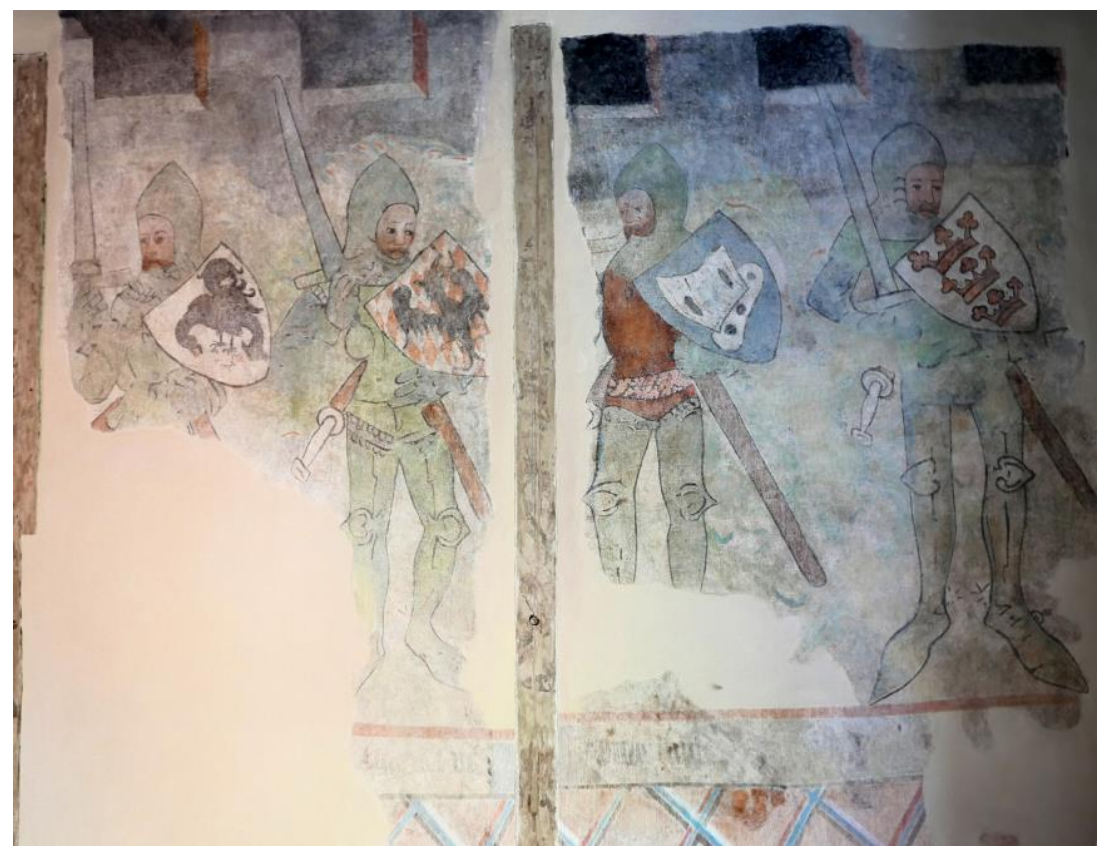

Il. 10. Toruń, kamienica przy ul. Żeglarskiej 16. Malowidło na ścianie zachodniej w pomieszczeniu II kondygnacji (dawna świetlica), fragment cyklu Dziewięciu Bohaterów, 4. ćw. XIV w., fot. J. Raczkowski

lektualnej zleceniodawcy, świadomego symbolicznej nośności takich przedstawień - tu owa asymilacja ikonografii rycerskiej ma zapewne funkcję nobilitującą i może wyrażać dumę rodową.

s. 114-115. W Italii temat Uomini illustri pojawił się w dekoracji wnętrz ratuszowych od lat 80. XIV w., np. niezachowane malowidła w Palazzo Vecchio we Florencji, 1381/1382; cykl Taddea di Bartolo w Anticapella Palazzo Pubblico w Sienie z lat 1413-1414, zob. D. Zachmann, Wandmalerei in Wohnhäusern toskanischer Städte im 14. Jahrhundert. Zwischen elitären Selbstverständnis und kommunalen Wertesystemen, (,Italienische Forschungen des Kunsthistorischen Institutes in Florenz”, Max Planck-Institut in Florenz, I Mandorli 21), Berlin 2016, s. 82. O roli toposu Dziewięciu Bohaterów w kulturze miast niderlandzkich w późnym średniowieczu i później, w okresie nowożytnym: W. van Androoij, Helden van weleer. De Negen Besten in de Nederlanden (1300-1700), Amsterdam 1997, s. 167-196. 
Z kolei na ścianie południowej ponad strefą patronową przedstawiona została (zachowana niestety szczątkowo) scena Modlitwy w Ogrój$c u^{62}$ (il. 11), o spiętrzonej, dynamicznej kompozycji, zapewne niegdyś na pejzażowym tle. Pole obrazowe jest tu dodatkowo odizolowane od strefy patronowej za pomocą fryzu architektonicznego, z iluzjonistycznie malowanymi arkadkami. Kompozycja malarska obejmowała prawdopodobnie całą ścianę, ale ani zasięg, ani treści malowidła po lewej stronie od dawnego kominka nie są dziś uchwytne ${ }^{63}$. Po stronie prawej zachowały się postać klęczącego Chrystusa oraz słabo czytelne fragmenty przedstawień śpiących apostołów. Pod względem ikonograficznym przedstawienie to jest równie rzadkie, jak cykl Dziewięciu Bohaterów: jest to jeden $\mathrm{z}$ dwóch zaledwie przykładów treści pasyjnych $\mathrm{w}$ toruńskich kamienicach mieszczańskich, jakie przetrwały do naszych czasów $^{64}$. Ponadto w końcu XIV w. scena Modlitwy w Ogrójcu była jeszcze stosunkowo „młoda”. Wpisywała się w potrzeby szeroko rozumianej devotio moderna, akcentowała ludzką słabość Zbawiciela, a zarazem dostarczała modlitewnego exemplum (wizerunek Chrystusa w pozie genuflexio można traktować jako wzór imitatio pietatis ${ }^{65}$ ). Obecność tej sceny we wnętrzu o funkcjach na poły reprezentacyjnych, na poły mieszkalnych oraz jej zestawienie z cyklem Dziewięciu Bohaterów niełatwo $z$ dzisiejszej perspektywy w pełni uzasadnić. Wybór tematu nie był raczej przypadkowy, ale trudno rozstrzygnacé, czy mamy tu do czynienia $z$ „modnym” cytatem $z$ wystroju kościelnego ${ }^{66}$, ze świadectwem indywidualnych potrzeb mieszkańców ${ }^{67}$, czy raczej z zewnętrzną

\footnotetext{
$621,5 \mathrm{~m}$ wys.

${ }^{63}$ Zachowały się jedynie nieczytelne relikty; kwestia, czy była to kontynuacja sceny ogrójcowej, czy tez znajdowało się tam inne przedstawienie, musi pozostać otwarta.

${ }^{64}$ Drugi przykład stanowi niewielka grupa Ukrzyżowania z 1. ćw. XV w. w izbie przy ul. Piekary 37.

${ }^{65}$ Szeroko na ten temat F. O. Büttner, op. cit., s. 47-55.

${ }^{66} \mathrm{Z}$ tego samego czasu pochodzi rzeźba Chrystusa Ogrójcowego, przechowywana w Muzeum Zamkowym w Malborku, wiązana przez wielu badaczy z kościołem staromiejskim w Toruniu. Zob. jako pierwszy: A. Dobry, Rzeźba Chrystusa w Ogrójcu ze zbiorów Muzeum Zamkowego w Malborku, Nasza Przeszłość 80 (1993), s. 107-130.

${ }^{67}$ Być może traktować go należy jako wyraz szczególnej pobożności Jakuba I Reussa, który zmarł w 1408 r. podczas pielgrzymki do Rzymu, zob. M. Gumowski, Herbarz patrycjatu toruńskiego, Toruń 1970, s. 146; K. Mikulski, K. Kopiński, op. cit., s. 174.
} 


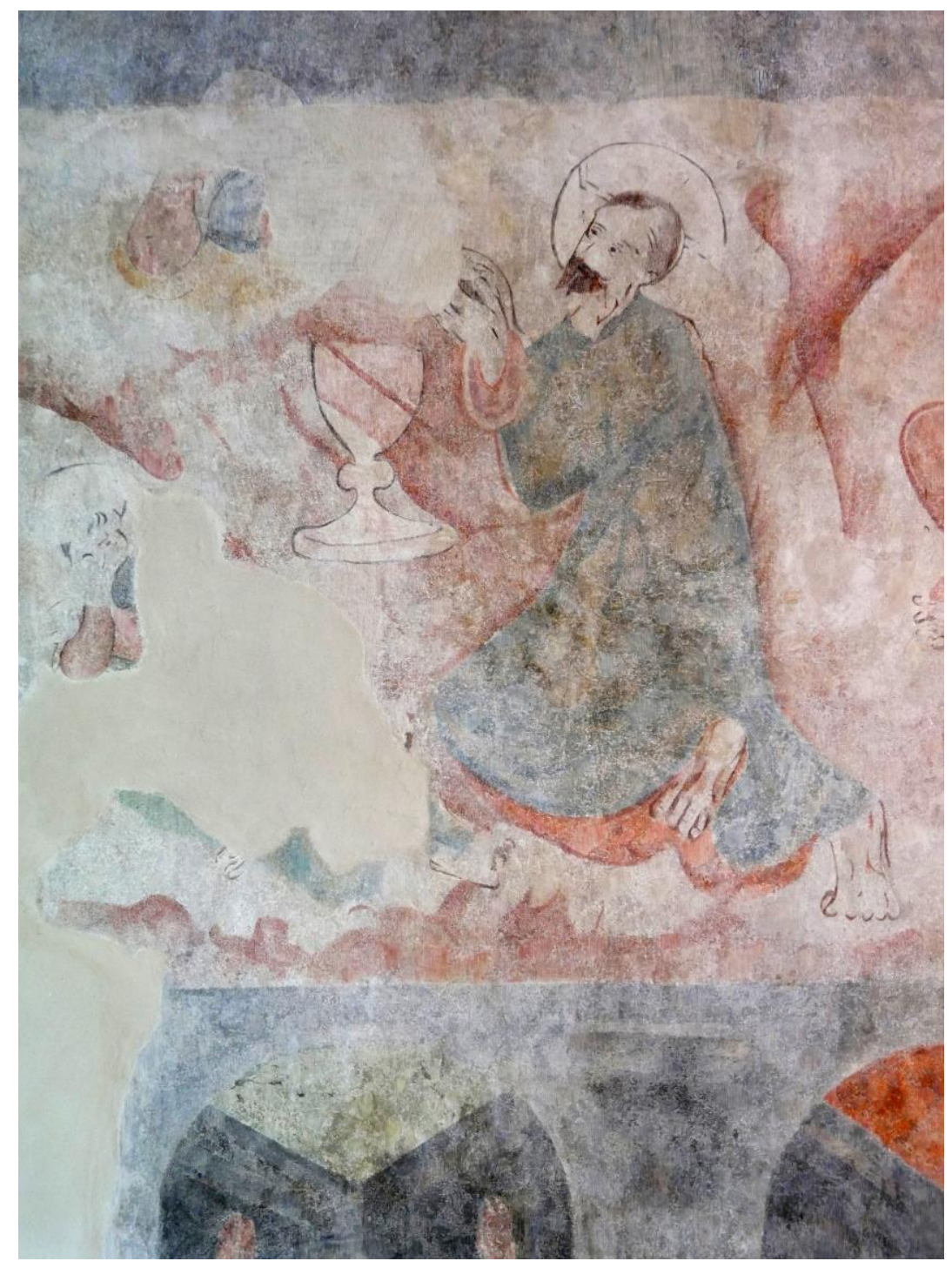

Il. 11. Toruń, kamienica przy ul. Żeglarskiej 16. Malowidło na ścianie południowej w pomieszczeniu II kondygnacji (dawna świetlica), fragment Modlitwy w Ogrójcu, 4. ćw. XIV w., fot. J. Raczkowski 
ostentacją postawy religijnej, stanowiącej część mieszczańskiej tożsamości.

Malowidła zachowały się, niestety, w bardzo złym stanie - warstwa malarska jest silnie spudrowana, na ścianie południowej kompozycja zachowała się w zasadzie jako szkic z lekkimi podmalówkami, na ścianie północnej dominują linearne kontury wykończenia, wzmocnione podczas prac konserwatorskich. Mimo to wyraźnie czytelna jest bohemizująca stylistyka tych malowideł, nawiązująca do stylu mistrza Teodoryka z Pragi i zbliżona do dekoracji domu przy Rynku Staromiejskim 10. Choć stan zachowania warstw malarskich w obu przypadkach jest szczątkowy w stosunku do pierwotnego opracowania, nie można się oprzeć wrażeniu, że oba malowidła były dziełem tego samego warsztatu. Łączy je predylekcja do krzywoliniowych miękkich układów kompozycyjnych, lekka konwencja malarska $\mathrm{z}$ dominacją płynnego konturu, a także charakterystyka postaci i opracowanie detali.

Wskazane tu przykłady nieznanych dotąd bliżej zabytków stanowią ważne uzupełnienie stanu zachowania gotyckich polichromii we wnętrzach świeckich, a zarazem - istotne ogniwa w charakterystyce sztuki Torunia w XIV w. Pod względem chronologii i stylu reprezentują dwa różne okresy w prężnym rozwoju lokalnego malarstwa ściennego - malowidło z Różanej 1 należy do fazy kształtowania się środowiska artystycznego około połowy stulecia, a trzy pozostałe powstały w okresie jego najbujniejszego rozkwitu (około 1390). Z punktu widzenia treści i funkcji nowe odkrycia stanowią niezwykle ważny przyczynek do rozpoznania predylekcji estetycznych, potrzeb religijnych i środków ostentacji statusu w kręgu staromiejskich elit. 